\title{
AKIBAT HUKUM PENGUNDUHAN KARYA CIPTA FOTOGRAFI DALAM MEDIA SOSIAL INSTAGRAM DAN PERLINDUNGANNYA
}

\author{
Shabilla Nur Aisyah \\ Fakultas Hukum, Universitas Stikubank (UNISBANK) Semarang \\ Email: shbllaisyah@gmail.com
}

\begin{abstract}
ABSTRAK
Karya Cipta Fotografi dalam Istagram diatur dalam Pasal 40 ayat (1) huruf k UU nomor 28 Tahun 2014 Tentang Hak Cipta. Latar belakang penelitian ini adalah masyarakat kurang memahami akan adanya unsur perlindungan hak cipta dalam setiap karya fotografi yang diunggah dalam media sosial instagram. Ketika seseorang melakukan pengunduhan karya fotografi tanpa ijin dari pemilik karya, walaupun hal ini sudah sering dilakukan, akan tetapi dari sisi hukum akan ada akibat hukumnya dan bahkan menimbulkan sanksi. Permasalahannya adalah adakah negara memberikan perlindungan terhadap kaarya cipta fotografi dan apa akibat hukumnya apabila pengunduhan dilakukan tanpa ada ijin. Metode yang digunakan dalam penelitian ini adalah yuridis normatif, yaitu penelitian yang didasarkan pada data data sekunder, yang kemudian dianalisa secara kualitatif dan disajikan dalam bentuk kualitatif.

Hasil penelitian menunjukkan bahwa negara telah melindungi karya cipta fotografi, melalui Pasal 1365 jo 1367 KIHPer, Pasal 25 UU No 19 Tahun 2016 Tentang Informasi dan Transaksi Elektronik, Pasal 40 ayat (1) huruf k dan Pasal 59 UU No 28 Tahun 2014 Tentang Hak Cipta dan Peraturan Bersama Menteri Hukum dan HAM dan Menteri Komunikasi dan Informatika No 14 Tahun 2015 dan No 26 Tahun 2015. Akibat hukum apabila seseorang melakukan pengunduhan tanpa ijin maka berdasarkan Pasal 113 UU Hak Cipta, dapat dipidana maksimal 4 tahun penjara dan /atau denda maksimal 1 Milyar, berdasarkan Pasal 48 UU ITE pidana penjara $8-9$ tahun dan/atau denga $2 \mathrm{M}$.
\end{abstract}

Kata Kunci : Perlindungan Hukum, Hak Cipta, Fotografi,Media Sosial 


\begin{abstract}
Photography copyright works in Istagram are regulated in Article 40 paragraph (1) letter k of Law number 28 of 2014 concerning Copyright. The background of this research is that the public does not understand the element of copyright protection in every photographic work uploaded on Instagram social media. When someone downloads a photographic work without the permission of the owner of the work, even though this has often been done, from a legal standpoint there will be legal consequences and even lead to sanctions. The problem is whether the state provides protection for photographic copyrighted works and what are the legal consequences if the download is done without permission. The method used in this research is normative juridical, namely research based on secondary data, which is then analyzed qualitatively and presented in a qualitative form.

The results show that the state has protected photographic copyright works, through Article 1365 jo 1367 KIHPer, Article 25 of Law No. 19 of 2016 concerning Electronic Information and Transactions, Article 40 paragraph (1) letter k and Article 59 of Law No. 28 of 2014 concerning Copyright and Joint Regulations of the Minister of Law and Human Rights and the Minister of Communication and Information Technology No. 14 of 2015 and No. 26 of 2015. The legal consequence is that if a person makes a download without permission, under Article 113 of the Copyright Law, he can be sentenced to a maximum of 4 years in prison and / or a maximum fine of 1 Billion, based on Article 48 of the ITE Law, imprisonment of 8 9 years and / or $2 \mathrm{M}$.
\end{abstract}

Keywords: Legal Protection, Copyright, Photography, Social Media 


\section{PENDAHULUAN}

Seiring dengan berkembangnya jaman maka akan diikuti pula dengan berkembangnya teknologi. Kemajuan teknologi tentunya dapat memberikan kemudahan terhadap penggunanya untuk memperkenalkan karyanya. Seperti yang dapat dilihat pada jaman sekarang ini, perkembangan teknologi yang semakin pesat membawa media sosial juga semakin berkembang dengan sangat pesat, yang mana media sosial adalah aplikasi yang dapat digunakan untuk berbagi informasi, media sosial dapat diakses oleh berbagai kalangan masyarakat dengan mudah, mulai dari kalangan anak-anak, remaja, hingga orang dewasa sebagian besar memiliki sosial media yang aktif. Hal ini dapat memberikan dampak pada sebuah karya cipta salah sataunya adalah karya cipta fotografi yang saat ini dapat lebih mudah diperkenalkan kepada masyarakat luas dengan cara dimuat dalam salah satu aplikasi media sosial yaitu instagram.

Dalam akun media sosial instagram seseorang, ada kalanya pemilik akun akan mengunggah sebuah karya fotografinya. Perbuatan menciptakan atau menghasilkan sebuah karya seni dapat dilakukan oleh semua orang, hal ini membuat apa saja dapat dijadikan objek dari karya cipta fotografi ${ }^{1}$. Karya fotografi pada awalnya masih memakai media film namun seiring dengan berkembangnya teknologi, karya fotografi tidak lagi menggunakan media film untuk merekam atau menangkap pantulan cahaya pada obyek melainkan saat ini sudah berbentuk suatu file digital yang dapat mempermudah orang lain untuk meng-copy atau mencetak hasil dari foto tersebut. Dengan adanya file digital itu, dapat mempermudah orang lain untuk memanfaatkan karya fotografi seseorang untuk berbagai kepentingan sendiri tanpa mencantumkan nama pencipta atau pemegang hak cipta maupun tanpa sepengetahuan penciptanya dengan cara menggandakan atau mengambil karya fotografi tersebut pada media sosial instagram pribadi miliknya. Hal ini yang dapat mengakibatkan timbulnya

\footnotetext{
${ }^{1}$ Rifal Al Arif, Perlindungan Hukum Atas Karya Cipta Fotografi Oleh Kementrian Hukum Dan Hak Asasi Manusia Di Daerah Istimewa Yogyakarta , Fakultas Syaria'ah dan Hukum Universitas Islam Negeri Sunan Kalijaga, Yogyakarta, 2016
}

permasalahan- permasalahan hukum yang berkaitan dengan hak cipta.

Hak cipta diatur dalam Pasal 1 Ayat 1 Undang-Undang Nomor 28 Tahun 2014 tentang Hak Cipta bahwa "Hak Cipta merupakan hak eksklusif pencipta atau pemegang hak cipta yang timbul secara otomatis berdasarkan prinsip deklaratif apabila suatu ciptaan sudah diwujudkan dalam bentuk nyata tanpa mengurangi pembatasan yang sesuai dengan ketentuan peraturan perundang- undangan".

Mengenai apakah karya fotografi yang sudah diunggah ke media sosial instagrammerupakan milik umum atau tidak, bahwa perlu diketahui hak cipta timbul dengan secara otomatis berdasarkan prinsip deklaratif setelah suatu ciptaannya diwujudkan dalam bentuk nyata. Maka pengumuman kepada publik justru semakin menegaskan timbulnya hak cipta tersebut. Akan tetapi, suatu ciptaan yang dilindungi hak cipta dapat menjadi milik publik (public comain) apabila jangka waktu perlindungannya telah berakhir. Jangka waktu perlindungan Hak Cipta atas karya fotografi berlaku selama 50 tahun sejak pertama kali dilakukan pengumuman ${ }^{2}$. Undang-Undang Hak Cipta sendiri tidak mengatur tentang perpanjangan jangka waktu perlindungan cak Cipta. Oleh karena itu, selama masih dalam jangka waku perlindungan hak ciptanya, maka karya fotografi tersebut bukanlah milik umum, melainkan milik pemegang hak cipta. Akan tetapi jika ciptaan tersebut telah lewat jangka waktu dari perlindungan hak ciptanya, maka masa berlaku hak ekonomi atas ciptaan karya fotografi tersebut telah berakhir. Pada saat karya ciptanya sudah tidak dilindungi oleh hak cipta lagi, maka pada saat itulah karya ciptanya dapat digunakan oleh pihak lain tanpa seizin dari pemilik hak cipta atau karya ciptanya bisa menjadi milik umum (public domain).

Berdasarkan uraian diatas penyusun tertarik untuk mengkaji dan mneganalisis

\footnotetext{
2 Abi Jan'am Kurnia, S.H, 2018, Hukumnya Mencuri Foto Online Shop Di Instagram,https://www.hukumonline.com/klinik/detai 1/1t5a715daf6a4b3/hukumnya-mencuri-fotoonlineshop-di-instagram/,diakses pada hari Selasa 3 Desember 2019
} 
lebih mendalam mengenai :akibat Hukum pengunduhan Karya Cipta Fotografi Dalam Media Sosial Instagram dan perlindungannya.

\section{Metode Penelitian \\ Jenis Penelitian}

Jenis penelitian ini adalah yuridis normatif. Penelitian Hukum (legal search) adalah penilitian yang dilakukan untuk menemukan kebenaran koherensi, yaitu adakah aturan hukum sesuai norma hukum dan adakah norma yang berupa perintah atau larangan itu sesuai dengan prinsip hukum, serta apakah tindakan (act) seseorang sesuai dengan norma hukum (bukan hanya sesuai aturan hukum) atau prinsip hukum ${ }^{3}$.

\section{Metode Pendekatan}

Metode pendekatan yang digunakan dalam penelitian ini adalah pendekatan yuridis normatif. Pendekatan yuridis adalah suatu pendekatan yang mengacu pada hukum dan peraturan perundang- undangan yang berlaku $^{4}$, sedangkan pendekatan normat if adalah pendekatan yang dilakukan dengan cara meneliti bahan pustaka atau data sekunder terhadap asas-asas hukum serta studi kasus yang dengan kata lain sering disebut sebagai penelitian hukum kepustakaan ${ }^{5}$.

\section{Spesifikasi}

\section{Penelitian}

Dalam penelitian ini digunakan spesifikasi penelitian secara deskriptif analistis. Penelitian deskriptif adalah suatu metode dalam meneliti status sekelompok manusia, suatu objek, suatu set kondisi, suatu sistem pemikiran, ataupun suatu kelas peristiwa pada masa sekarang6 ${ }^{6}$. Sedangkan analistis, adalah suatu usaha untuk mengurangi suatu masalah atau fokus kajian menjadi bagian- bagian (decomposition) sehingga susunan atau tatanan bentuk sesuatu yang diurai itu tampak dengan jelas dan karenanya bisa secara lebih

\footnotetext{
${ }^{3}$ Peter Mahmud Marzuki, Penelitian Hukum, Kencana Prenada Media Group, Jakarta, 2017, hlm 60

${ }^{4}$ Roni Hanitjo Soemitro, Metode Penelitian Hukum dan Jurimetri, Ghalia Indonesia, Jakarta, 1982, hlm 20

5 Soejono Soekanto dan Sri Mamudji, Penelitian Hukum Normatif Suatu Tinjauan Singkat, PT. Raja Grafindo Persada, Jakarta, 2004, hlm 13

${ }^{6}$ Nazir, Metode Penelitian, Ghalia Indonesia, Bogor, 2014, hlm 43
}

terang ditangkap maknanya atau lebih jerning dimengerti duduk perkaranya ${ }^{7}$.

\section{Metode Pengumpulan Data}

Penelitian ini menggunakan jenis data sekunder dan data primer, yang mana dalam menggunakan data sekunder peneliti melakukan teknik pengumpulan data yang dilakukan melalui wawancara secara langsung antara penulis dengan responden yaitu para pemilik hak cipta yang karya fotografinya disalahgunakan oleh pihak-pihak lain yang tidak bertanggung jawab dalam media sosial instagram. Sedangkan dalam penggunaan data sekunder peneliti melakukan pengumpulan data yang diperoleh dari keterangan secara tidak langsung melalui beberapa literature, dokumen resmi, laporan peraturan perundang-undangan yang ada hubunganya dengan masalah yang diteliti.

\section{Metode Analisis Data}

Metode digunakan
dalam menganalisis yang data-data yang terkumpul adalah analisis kualitatif. Metode kualitatif adalah metode penelitian yang berlandaskan pada filsafat postpositivisme, digunakan untuk meneliti pada kondisi objek alamiah, (sebagai lawannya adalah eksperimen) dimana peneliti adalah sebagai instrument kunci, teknik pengumpulan data yang dilakukan secara triagulasi (gabungan), analisis data bersifat induktif atau kualitatif,dan hasil penelitian kualitatif lebih menekankan makna daripada generalisasi.

\section{Pembahasan}

\section{Perlindungan Hukum Atas Karya Cipta Fotografi Yang Diunggah Dalam Media Sosial Instagram Tanpa Izin Pencipta}

Perlindungan hukum dibuat untuk melindungi hak pencipta atau pemegang hak cipta dalam segala hal yang mencakup pendistribusian karya, menjual ataupun membuat lanjutan atau turunan dari karya yang telah diciptakan sebelumnya. Terdapat dua bentuk perlindungan hukum yang diberikan yaitu perlindungan hukum yang bersifat preventif (pencegahan) maupun dalam bentuk represif (pemaksaan), baik secara tertulis maupun tidak tertulis. Menurut Philipus M. Hadjon perlindungan hukum preventif yaitu bentuk perlindungan hukum dimana masyarakat diberi kesempatan untuk mengajukan keberatan atau pendapat sebelum suatu keputusan pemerintah

\footnotetext{
7 Aan Komariah dan D'jam Satori, Metodologi Penelitian Kualitatif, Alfabeta, Bandung, 2014, hlm 200
} 
perlindungan hukum dimana lebih ditujukan dalam hal penyelesaian sengketa ${ }^{8}$.

\section{a. Perlindungan Hukum Dalam Undang- Undang Nomor 28 Tahun 2014 Tentang Hak Cipta}

Dalam hal ini karya fotografi termasuk dalam Hak Kekayaan Intelektual khususnya Hak Cipta yang diatur dalam Pasal 40 Ayat (1) huruf k Undang-Undang Nomor 28 Tahun 2014. Yang dimaksud dengan "karya fotografi" disini adalah yang mencakup semua foto yang diciptakan atau didapatkan melalui kamera.

Karya cipta fotografi adalah suatu ciptaan yang dilindungi secara eksklusif mengingat bahwa karya fotografi merupakan suatu ciptaan yang diwujudkan dalam bentuk nyata, seperti yang telah dijelaskan dalam Pasal 4 Undang-Undang Hak Cipta Tahun 2014 yang menjelaskan bahwa :

"Hak cipta adalah hak eksklusif yang mengandung dua esensi yakni hak moral dan juga hak ekonomi"

Dalam Pasal 59 Undang-Undang Nomor 28 Tahun 2014 memberikan perlindungan hak cipta atas ciptaan karya fotografi yang berlaku selama 50 (lima puluh) tahun sejak pertama kali dilakukan pengumuman.

Dengan adanya hal tersebut maka Undang-Undang Nomor 28 Tentang Hak Cipta telah memberikan perlindungan kepada pencipta atau pemegang hak cipta dengan mendaftarkan ciptaannya seperti yang sudah tertera di dalam Bab X UndangUndang Hak Cipta tentang Pencatatan Ciptaan mulai dari Pasal 64 sampai dengan Pasal 79, yang mana di dalam Pasal 64 Ayat (1) menjelaskan bahwa "Menteri menyelenggarakan pencatatan dan penghapusan ciptaan dan produk hak terkait". Namun dalam Pasal 64 ayat (2) menjelaskan bahwa pencatatan ciptaan dan produk hak terkait sesuai ayat (1) bukanlah syarat untuk mendapatkan hak cipta dan hak terkait.

Upaya lain yang dilakukan pemerintah terkait dengan perlindungan hukum terhadap pelanggaran hak cipta karya fotografi adalah dengan adanya Peraturan Bersama Menteri Hukum dan Hak Asasi Manusia Republik Indonesia dan Menteri Komunikasi dan Informatika Republik Indonesia Nomor 14 Tahun 2015 dan Nomor 26 Tahun 2015 tentang Pelaksanaan Penutupan Konten dan/ atau Hak Akses Pengguna Pelanggaran Hak

\footnotetext{
${ }^{8}$ Glosarium, 2014, Pengertian Perlindungan Hukum Menurut Para Ahli, http://tesishukum.com/pengertianperlindunganhukum-menurut-para-ahli/ , diakses pada hari Sabtu 16 Mei 2020
}

Cipta dan/atau Hak Terkait Dalam Sistem Elektronik. Dalam peraturan ini menjelaskan bahwa pelaporan pelanggaran hak cipta dapat dilakukan melalui media elektronik maupun non elektronik.

\section{b. Perlindungan Hukum Dalam Kitab Undang- Undang Hukum Perdata (KUH Perdata)}

Secara umum, perlindungan terhadap pelanggaran karya cipta fotografi tertuang dalam Buku III BW, pada bagian "Tentang perikatan- perikatan yang dilahirkan demi Undang-Undang", meskipun dalam Kitab Undang-Undang Hukum Perdata (KUHPer) tidak menjelaskan secara jelas tentang perlindungan terhadap karya ciptaan fotografi, namun dengan adanya tindakan pelanggaran karya cipta fotografi yang diunggah dalam media sosial tanpa izin pencipta merupakan suatu perbuatan yang melawan hukum. Perbuatan melawan hukum diatur dalam Pasal 1365 Kitab UndangUndang Hukum Perdata (KUHPer), yang menjelaskan bahwa "Tiap perbuatan yang melanggar hukum dan membawa kerugian kepada orang lain, mewajibkan orang yang menimbulkan kerugian tersebut kerena kesalahanya untuk menggantikan kerugian tersebut".

Dalam Pasal $1367 \quad$ KUHPerdata juga menjelaskan bahwa "seseorang tidak hanya bertanggung jawab atas kerugian yang disebabkan perbuatannya sendiri, melainkan juga atas kerugian yang disebabkan perbuatan-perbuatan orang-orang yang menjadi tanggungannya atau disebabkan barang-barang yang berada dibawah pengawasannya."

\section{c. Perlindungan Hukum Dalam Undang-} Undang Nomor 19 Tahun 2016 Tentang Perubahan Atas Undang-Undang Nomor 11 Tahun 2008 Tentang Informasi dan Transaksi Elektronik

Dalam Undang-Undang Nomor Nomor 19 Tahun 2016 tentang Perubahan Atas Undang- Undang Nomor 11 Tahun 2008 tentang Informasi dan Transaksi Elektronik foto dapat dikatakan sebagai informasi elektronik dan/atau dokumen elektronik apabila masih berbentuk elektronik (jika belum dicetak). Sebagaimana yang terdapat dalam Pasal 1 Ayat (1) dan (4) UndangUndang Informasi Teknologi Elektronik.

Kemudian di dalam Pasal Seperti yang telah dijelaskan dalam Pasal 25 Undang-Undang ITE yang menjelaskan bahwa :

"Informasi elektronik dan/atau dokumen elektronik yang disusun menjadi karya intelektual, situs internet, dan karya intelektual yang ada di dalamnya 
dilindungi sebagai Hak Kekayaan Intelektual berdasarkan Ketentuan Peraturan PerundangUndangan".

Maka dalam hal ini karya cipta fotografi yang diunggah dalam media sosial instagram adalah sesuatu informasi elektronik tau dokumen elektronik yang mendapatkan perlindungan dalam UndangUndang ITE jika terjadi suatu pelanggaran terhadap karya cipta fotografi yang dapat merugikan pencipta atau pemegang hak cipta.

\section{d. Perlindungan Hukum Dalam Media} Sosial Instagram

Instagram memiliki Ketentuan Pengguna pada halaman Pedoman Komunitas yang menjelaskan bahwa instagram telah membuat Pedoman Komunitas sehingga pengguna diharapkan dapat membantu instagram untuk menumbuhkan dan melindungi komunitas yang telah dibuat.

Pelanggaran terhadap batasanbatasan yang telah tercantum dalam pedoman instagram akan mengakibatkan pihak instagram untuk melakukan penghapusan konten, penonaktifan akun, atau larangan-larangan lainnya.

Akibat Hukum Bagi Pengunduh Karya Cipta Fotografi Dalam Media Sosial Instagram Tanpa Izin Pencipta Baik Untuk Diunggah Kembali Secara Pribadi atau Diunggah Kembali Untuk Dikomersilkan

Dewasa ini banyak terjadi modus penipuan yang terjadi dalam media sosial, terutama dalam media sosial instagram yang mana notabennya instagram merupakan tempat untuk berbagi foto untuk kepentingan pribadi maupun untuk kepentingan komersil.

Kurangnya pengetahuan masyarakat akan arti dan fungsi hak cipta yang menyebabkan munculnya beberapa kasus yang berhubungan dengan penyalahgunaan hak-hak pencipta atas suatu karya fotografi yang terjadi dalam media sosial instagram, berawal dari sebuah pelanggaran yang dilakukan oleh seseorang dengan mengakui suatu ciptaan karya fotografi tersebut merupakan karya ciptaannya sendiri yang kemudian diunduh dan diunggah kembali dalam media sosial instagram tanpa izin pencipta baik untuk digunakan secara untuk kepentingan pribadi maupun untuk kepentingan komersil.

\section{a. Akibat Hukum Dalam Undang- Undang \\ Nomor 28 Tahun 2014 tentang Hak Cipta}

Perbuatan mengunggah karya fotografi tanpa izin pemilik hak cipta dalam media sosial instagram baik untuk diunggah kembali secara pribadi atau diunggah kembali untuk dikomersilkan merupakan suatu pelanggaran terhadap karya fotografi baik dari segi hak moral maupun hak ekonomi.

Seperti yang sudah dijelaskan sebelumnya bahwa sesuai dengan pasal 9 ayat (2) Undang- Undang Hak Cipta yang menjelaskan bahwa jika terdapat pihak ketiga yang ingin menggunakan hak ekonomi pencipta, maka pihak ketiga tersebut harus mendapatkan izin pencipta atau pemegang hak cipta. Izin yang diberikan pencipta atau pemegang hak cipta kepada pihak ketiga yang menggandakan atau mengumumkan ciptaan dan memiliki persyaratan tertentu disebut dengan lisensi. Sedangkan di dalam Pasal 9 ayat (3) Undang-Undang Hak Cipta juga menjelaskan tentang larangan dalam hal menggandakan atau menggunakan suatu ciptaan termasuk karya cipta fotografi secara komersial tanpa izin pencipta atau pemegang hak cipta.

Apabila telah terjadi pelanggaran tersebut, maka pemilik hak cipta dapat mengajukan gugatan perdata yang berupa ganti rugi, seperti yang sudah tertuang dalam Pasal 96 Undang-Undang Nomor 28 Tahun 2014 tentang Hak Cipta.

Selain dapat mengajukan gugatan perdata, pemilik hak cipta juga berhak melakukan tututan pidana terhadap pelaku pelanggaran hak cipta karya fotografi yang diunggah tanpa izin pemilik hak cipta. Pemberian sanksi terhadap pelanggaran hak cipta karya fotografi dalam hal penggandaan dan pendistribusian tercantum dalam Pasal 113 ayat (3) Undang-Undang Nomor 28 Tahun 2014 tentang Hak Cipta yang menjelaskan bahwa:

"Seseorang yang tidak memiliki hak dan/atau izin pencipta atau pemegang hak cipta atau pemegang cipta melakukan suatu pelanggaran terhadap hak ekonomi pencipta atau pemegang hak cipta seperti yang dimaksud dalam Pasal 9 ayat (1) huruf a, 
huruf $b$, huruf e, dan/atau huruf $g$ demi penggunaan secara komersial dapat dipidana dengan pidana penjara paling lama 4 (empat) tahun dan/atau pidana denda paling banyak Rp. 1.000.000.000,00 (satu miliar rupiah)."

\section{b. Akibat Hukum Dalam Undang-Undang} Nomor 19 Tahun 2016 Tentang Perubahan atas Undang-Undang Nomor 11 Tahun 2008 Tentang Informasi dan Transaksi Elektronik

Akibat hukum pelanggaran karya cipta fotografi juga berkaitan dengan Undang-Undang Nomor 19 Tahun 2016 Tentang Perubahan atas Undang-Undang Nomor 11 Tahun 2008 Tentang Informasi dan Transaksi Elektronik yang disebut juga dengan UU ITE. Berikutnya terdapat sanksi yang didapat atas pelanggaran hak cipta seperti yang telah dijelaskan dalam Pasal 32 Ayat (1) dan (2) UU ITE dan Pasal 48 Ayat (1) dan (2) UU ITE yang menjelaskan bahwa:

Pasal 32 ayat (1) "Setiap orang dengan sengaja dan tanpa hak atau melawan hukum dengan cara apa pun mengubah, menambah, mengurangi, melakukan transmisi, merusak, menghilangkan, memindahkan, menyembunyikan suatu Informasi Elektronik dan/atau Dokumen Elektronik milik orang lain atau milik publik".

Pasal 32 ayat (2) "Setiap orang dengan sengaja dan tanpa hak atau melawan hukum dengan cara apa pun memindahkan atau mentransfer Informasi Elektronik dan/atau Dokumen Elektronik kepada Sistem Elektronik orang lain yang tidak berhak".

Pasal 48 ayat (1) UU ITE "Setiap orang yang memenuhi unsur sebagaimana dimaksud dalam Pasal 32 ayat (1) dipidana dengan pidana penjara paling lama 8 (delapan) tahun dan/atau denda paling banyak Rp 2.000.000.000,00 (dua miliar rupiah)."

Pasal 48 ayat (2) UU ITE “ Setiap orang yang memenuhi unsur sebagaimana yang dimaksud dalam Pasal 32 ayat (2) dipidana dengan pidana penjara paling lama 9 (sembilan) tahun dan/atau denda paling banyak Rp. 3.000.000.000,00 (tiga miliar rupiah)."

\section{KESIMPULAN DAN SARAN Kesimpulan}

Berdasarkan rumusan masalah dan hasil pembahasan yang telah penulis paparkan sebelumnya, maka penulis dapat memberikan kesimpulan sebagai berikut :

1. Bentuk perlindungan hukum karya cipta fotografi dalam media sosial instagram telah diatur dalam Undang-Undang Nomor 28 Tahun 2014 Tentang Hak Cipta. Perlindungan karya cipta fotografi dalam media sosial instagram adalah perlindungan hukum yang bersifat prepentiv dan represif, Perlindungan hukum prepentiv dapat dilakukan dengan cara mendaftarkan ciptaannya kepada Direktorat Jenderal Kekayaan Intelektual Kementrian Hukum dan HAM. Sedangkan dengan cara represif pelanggaran hak cipta dapat dilakukandengan cara mengajukan gugatan kepada Pengadilan Niaga pada Pengadilan Negeri.

2. Perlindungan hukum juga telah diatur dalam Kitab Undang-Undang Hukum Perdata (KUH Perdata), Undang Undang Nomor 19 Tahun 2016 Tentang Perubahan Atas UndangUndang Nomor 11 Tahun 2008 Tentang Informasi dan Transaksi Elektronik dan Peraturan Bersama Menteri Hukum dan Hak Asasi Manusia Republik Indonesia dan Menteri Komunikasi dan Informatika Republik Indonesia Nomor 14 Tahun 2015 dan Nomor 26 Tahun 2015 tentang Pelaksanaan Penutupan Konten dan/ atau Hak Akses. Media sosial instagram memiliki ketentuan yang wajib dipatuhi oleh setiap penggunanya, akan tetapi media sosial instagram tidak bertanggung jawab secara langsung atas pelanggaran hak cipta sehingga pertanggung jawaban dari media sosial instagram harus dimintakan seciara langsung oleh penggunanya. Selain itu bentuk perlindungan lain dilakukan oleh Menteri Telekomunikasi dan Informatika yang dapat menutup sebagian atau seluruh konten yang melanggar Hak Cipta.

3. Sanksi yang diberikan bagi pihak ketiga yang melakukan pelanggaran terhadap hak cipta karya fotografi dalam media sosial instagram tanpa izin pencipta akan mendapatkan sanksi secara perdata yaitu gugatan ganti rugi oleh pemilik Hak Cipta maupun sanksi secara pidana seperti yang telah diatur dalam Pasal 113 ayat (3) Undang-Undang Hak Cipta dan Pasal 48 ayat (1) dan (2) UU ITE. Sedangkan sanksi yang diberikan oleh 
Peraturan Bersama Menteri Hukum dan Hak Asasi Manusia Republik Indonesia dan Menteri Komunikasi dan informatika Republik Indonesia Nomor 14 Tahun 2015 Nomor 26 Tahun 2015 tentang Pelaksanaan Penutupan Konten dan/ atau Hak Akses dan dari pihak instagram sendiri akan memberikan sanksi dengan adanya penutupan konten atau hak akses kepada pihak ketiga Saran pelaku pelanggaran hak cipta.

Berdasarkan kesimpulan yang telah disebutkan diatas, maka penulis dapat memberikan saran sebagai berikut :

1. Perlu dilakasanakan sosialisasi oleh Pemerintah kepada masyarakat terkait dengan Undang-Undang Nomor 28 Tahun 2014 Tentang Hak Cipta dan cara pendaftaran hak cipta, dengan hal ini diharapkan masyarakat mengerti akan perlindungan Hak Cipta karya fotografi. Khususnya para fotografer. Untuk masyarakat diharapkan lebih bijak dalam menggunakan media sosial instagram, jika ingin mengambil suatu karya cipta fotografi seseorang di instagram, maka alangkah baiknya meminta izin terlebih dahulu dan mencantumkan nama pemilik karya foto tersebut.

2. Ketika terjadi suatu pelanggaran hak cipta upaya hukum harus ditegaskan agar pihak ketiga pelanggar hak cipta jera akan hal tersebut, dan proses penanggulangan tersebut harus dengan cepat ditangani, mengingat kehidupan media sosial instagram berkembang setiap detiknya. Hukum harus selalu mengikuti perkembangan yang ada pada zaman sekarang ini, agar para pengguna media sosial instagram merasa aman dan nyaman.
Pangarso,Golkar. 2015. Penegakan Hukum Perlidungan Ciptaan Sinematografi Bandung: Alumni.

Soekanto,Soejono dan Sri Mamudji. 2014. Penelitian Hukum Normaif Suatu Tinjauan Singkat. PT Raja Grafindo Persada

Soelistyo,Henry. 2011. Hak Cipta Tanpa Hak Moral. Jakarta: PT Rajagrafindo Persada.

Soemitro, Roni Hanitjo. 1982. Metode Penelitian Hukum dan Jurimetri. Jakarta: Ghalia Indonesia

\section{Jurnal}

Arif,Rifal Al. 2016. Perlindungan Hukum Atas Karya Cipta Fotografi Oleh Kementrian Hukum Dan Hak Asasi Manusia Di Daerah Istimewa Yogyakarta . Yogyakarta: Fakultas Syaria'ah dan Hukum Universitas Islam Negeri Sunan Kalijaga.

\section{Website}

Abi Jan'am Kurnia, S.H, 2018, Hukumnya Mencuri Foto Online Shop DiInstagram, https://www.hukumonline.co $\mathrm{m} / \mathrm{klinik} / \mathrm{de}$ tail/lt5a715daf6a4b3/hukumnya-mencurifoto- online-shop-di-instagram/, diakses pada hari Selasa 3 Desember 2019

Glosarium, 2014, Pengertian Perlindungan Hukum Menurut ParaAhli,http://tesishukum.com/pengertian - perlindungan-hukum-menurut-para-ahli/ ,diakses pada hari Selasa 3 Desember 2019

Romel Tea, 2014, Media Sosial: Pengertian, Karakteristik, dan Jenis, www.romelteamedia.com diakses pada hari Kamis 26 Maret 2020

Aw Putri, 2018, Pengguna Instagram Stories Sebagai Personal Branding, http://eprints.umm.ac.id/43019/5/BAB\%2 04.pdf, diakses pada hari Jumat 27 Maret

\section{DAFTAR PUSTAKA}

\section{Literatur}

Baharuddin. 2014. Fotografi. Yogyakarta: Graha Ilmu.

Komariah, Aan dan D'jam Satori. 2014. Metodologi Penelitian Kualitatif. Bandung: Alfabeta.

Marzuki, Peter Mahmud. 2017. Penelitian Hukum. Jakarta: Kencana Prenada Media Group

Nazir. 2014. Metode Penelitian. Bogor: Ghalia Indonesia. 